\title{
Batallas del pasado en tiempo presente. «Guerra antigua», civilización y pensamiento local en Lípez (dpto. de Potosí, Bolivia)
}

Batailles du passé au temps présent : "guerre ancienne», civilisation et pensée locale à Lípez (dép. de Potosi, Bolivie)

Battles of the past in present time: "ancient warfare», civilization and local knowledge in Lipez (Department of Potosi, Bolivia)

Francisco M. Gil García

\section{(2) OpenEdition}

\section{Journals}

Edición electrónica

URL: http://journals.openedition.org/bifea/5478

DOI: 10.4000/bifea.5478

ISSN: 2076-5827

Editor

Institut Français d'Études Andines

Edición impresa

Fecha de publicación: 1 agosto 2005

Paginación: 197-220

ISSN: 0303-7495

Referencia electrónica

Francisco M. Gil García, «Batallas del pasado en tiempo presente. «Guerra antigua», civilización y pensamiento local en Lípez (dpto. de Potosí, Bolivia)», Bulletin de l'Institut français d'études andines [En línea], 34 (2) | 2005, Publicado el 08 agosto 2005, consultado el 02 diciembre 2020. URL : http:// journals.openedition.org/bifea/5478; DOI : https://doi.org/10.4000/bifea.5478

\section{(c) (†) $९$}

Les contenus du Bulletin de l'Institut français d'études andines sont mis à disposition selon les termes de la licence Creative Commons Attribution - Pas d'Utilisation Commerciale - Pas de Modification 4.0 International. 


\title{
Batallas del pasado en tiempo presente. «Guerra antigua», civilización y pensamiento local en Lípez (dpto. de Potosí, Bolivia)
}

\author{
Francisco M. Gil García*
}

\begin{abstract}
Resumen
Este trabajo considera que la tradición oral acerca de la «guerra antigua» puede contribuir de manera interesante a la interpretación de la violencia en el pasado. Nos acercaremos así al análisis que, desde el pensamiento local, aplican las gentes de Lípez (dpto. de Potosí, Bolivia) a unas ruinas y a un registro arqueológico que apuntan a situaciones de tensión intergrupal y conflictos armados en épocas preincaica e incaica. En este sentido, contrastaremos los resultados obtenidos por la arqueología con aquella otra recreación histórica proveniente de una tradición oral que, además de hablar de la concepción del tiempo, ahonda en la propia concepción del Otro pretérito y reflexiona sobre los orígenes y formas de la guerra en el pasado.
\end{abstract}

Palabras clave - guerra, pukaras, alteridad, chullpas, incas, arqueología, tradición oral, Altiplano de Lípez

\section{Batailles du passé au temps présent : «guerre ancienne», civilisation et pensée locale à Lípez (dép. de Potosi, Bolivie)}

\section{Résumé}

Cette étude considère que la tradition orale à propos de la «guerre ancienne» peut contribuer, de façon intéressante, à l'interprétation de la violence dans le passé. Nous nous rapprocherons ainsi, à partir de la pensée locale, de l'analyse que les gens de Lípez (dép. de Potosí, Bolivie) font sur certaines ruines et à un registre archéologique qui révèle des indices de situations de tension à l'intérieur du groupe et de conflits armés aux époques pré-incasique et incasique. Pour ce faire, nous comparerons les résultats

Profesor del Dpto. de Historia de América II (Antropología de América). Facultad de Geografía e Historia. Ciudad Universitara s/n. Universidad Complutense de Madrid. 28040 - Madrid - España. E-mail: tachiyoc@hotmail.com 
obtenus en archéologie avec cette autre recréation historique en provenance d'une tradition orale qui, outre les allusions à la conception du Temps, approfondit la conception même de l'Autre et réfléchit sur les origines et les formes de la guerre dans le passé.

Mots clés - guerre, pukaras, altérité, chullpas, incas, archéologie, tradition orale, Altiplano de Lípez

\title{
Battles of the past in present time: «ancient warfare», civilization and local knowledge in Lípez (Department of Potosi, Bolivia)
}

\begin{abstract}
This paper argues that oral tradition about "ancient warfare" can contribute to the interpretation of violence in the past in an interesting manner. Thus, from the local knowledge we are able to approach the analysis on ruins and archaeological record in the Lípez (Department of Potosi, Bolivia) that points to inter-groups tension and armed conflicts in pre-Inca and Inca time. In this sense, we will contrast the archaeological results with the historical recreation from an oral tradition in a way that deals with the conception of time goes deeper into the into the conception of the Other and reflects on the origins and forms of past warfare.
\end{abstract}

Key words - Warfare, pukaras, alterity, chullpas, Incas, archaeology, oral tradition, Lípez Highland

Hablar de guerra no supone solo referirse al acto de luchar, sino también a una predisposición a empuñar las armas sobradamente conocida por todos los implicados, y a partir de la cual se garantiza la paz; un estado permanente de lucha simbólica en tanto que manipulación de las representaciones propias y reordenamiento de las categorías de percepción dentro del entramado social en pos del mantenimiento de un statu quo. En este sentido, una o varias murallas rodeando una ciudad constituyen a la vez un símbolo de su poder y un dispositivo de defensa, evocando así un clima bélico o, cuando menos, la amenaza potencial de la guerra. Ante una fortificación, aún cuando a sus pies reposen los cadáveres y los restos de armamento dejados tras el asedio, el arqueólogo simplemente podrá relevar una constante del comportamiento humano: la violencia. Podrá constatar la guerra, sí, pero con mayor dificultad será capaz de resolver sus causas. Además, la forma en que se conciba y se manipule esa violencia marcará el curso de la Historia: el poder se apoya en el ejercicio de la violencia, o al menos en el potencial simbólico de «la amenaza»... diferentes corrientes filosóficas reflexionan acerca de la violencia en la generación de los valores éticos y los destinos existenciales del ser humano... todas las religiones apelan en algún momento a la guerra («santa»). Así mismo, los modos de entender la guerra y el ejercicio de la violencia estarán marcando nuestra visión del otro, de un otro tan necesario para nuestra propia identidad y nuestra memoria histórica como es «el enemigo».

Ahora bien, zqué ocurre cuando el tiempo de los enfrentamientos se pierde en la memoria, cuando los combatientes gravitan en el pasado remoto, cuando quienes hacen la guerra son unos otros quizás demasiado antiguos? Quizás con aire de conclusión adelantada podría responder 
aquí que la lectura desde el presente de las batallas del pasado constituye un doble ejercicio de interpretación de la Historia: (re)construcción de los tiempos antiguos y a la vez (re)creación de los antiguos. De todo ello trata el presente trabajo: de fortalezas y batallas antiguas, de la concepción del tiempo mitohistórico y de la noción de persona aplicada a los habitantes de un pasado que se difumina entre lo histórico y lo mítico.

Se ha dicho que los arqueólogos, independientemente de su marco teórico, siempre acaban por hacer una reconstrucción del pasado a partir de su propia subjetividad. Además, en tanto que la realidad termina por convertirse en representaciones de ésta, la arqueología suele actuar como si su objeto de estudio fuera más la cultura material que el conocimiento de aquellas sociedades pretéritas que la generaron (Hernando, 1997: 247-248, 251). Ampliar entonces los puntos de vista respecto de lo que el registro arqueológico sugiere me parece que puede ayudar a superar estas ataduras y a encarar, por tanto, su interpretación con mayor grado de resolución. Así, lo que trataré de presentar a continuación son otros puntos de vista sobre el arte de la guerra en dos momentos de especial tensión bélica en la historia del altiplano centro-sur. Por un lado, el Período de Desarrollos Regionales del Tardío (ca. 1000 d. C. - expansión incaica), la «Edad de los Auca Runa», marcada por la pugna de diferentes señoríos étnicos en el contexto de una profunda reordenación político-económica-territorial del espacio altiplánico. En segundo lugar, la expansión del Tawantinsuyu y las luchas de conquista protagonizadas por los incas para someter a estos señoríos locales e incluirlos dentro de su imperio. En este sentido, las páginas que siguen quedan articuladas desde un vaivén entre el conocimiento arqueológico y etnohistórico al respecto, y desde los aportes que a este tema puede hacer la tradición oral desde la representación del pasado y sus habitantes.

Para ello recurriré a lo que llamo las historias de ruinas, un corpus narrativo etnográfico organizado a través de las analogías, las creencias y las opiniones de aquellas poblaciones que, en su vida cotidiana, conviven con los restos arqueológicos y las ruinas, y que reflexionan acerca de su naturaleza y sobre sus antiguos moradores dentro de sus propios esquemas mentales. Así, dando prioridad a una lectura emic del pasado y sus vestigios, pretendo con este trabajo profundizar en los esquemas de pensamiento local, en la lógica narrativa de su discurso histórico, y en los mecanismos de construcción y representación de la identidad y la alteridad. Desde esta óptica, creo firmemente que este tipo de otros análisis podría llegar a ser de gran ayuda para suscitar en los arqueólogos una mentalidad distinta a la hora de encarar el trabajo de campo. Por un lado, contemplando el pensamiento local sobre ruinas y restos arqueológicos, quizá algunos verían ampliadas sus miras de cara a preguntarse por el pasado y sus habitantes. Pero además, y esto sí me parece realmente importante, no cabe duda que considerar la perspectiva local contribuiría a concebir actuaciones concretas y políticas generales de gestión del Patrimonio mucho más compenetradas con la realidad socioeconómica de las comunidades.

Así, desarrollaré este análisis sobre la guerra antigua a partir de mis trabajos en Santiago «K»1 (Nor Lípez, dpto. Potosí, Bolivia), una comunidad agropastoril situada al sur del Salar de Uyuni, en torno a los $3700 \mathrm{msnm}$. Aquí vengo realizando investigación de campo en etnografía y etnoarqueología desde 2001, prestando especial atención al pensamiento local sobre las ruinas (Gil, 2005a) y los elementos significativos del paisaje, así como a la construcción narrativa del discurso histórico local y regional (Gil, 2005b; 2005c).

Por su localización en ese Sector Norte del Altiplano de Lípez (sensu clasificación geocultural de Nielsen, 1998) cuyas especiales condiciones climáticas y edafológicas permitieron la ocupación

1 Pudiera pensar algún lector que — siguiendo una práctica frecuente en algunas etnografías — estoy enmascarando aquí el nombre de la comunidad de Santiago «K», cuando en realidad se trata de este. La letra «K» responde a una antigua demarcación cantonal hoy en desuso, aunque mantenida todavía en algunos topónimos de Nor Lípez como parte incorporada a los mismos, aunque generalmente no verbalizada en el habla cotidiana. Así, en lo sucesivo me referiré a esta comunidad con el nombre abreviado de Santiago. 
sedentaria del espacio y el desarrollo de la agricultura, Santiago es una comunidad rodeada de sitios arqueológicos. De todos ellos, sin duda alguna, el más significativo es Laqaya (del quechua, «lugar de ruinas»), con sus aproximadamente 7 ha, ubicado al borde de una península rocosa en la falda de un cerro Llipi (uno de los mallkus de la comunidad), desde la cual se controla toda una fértil llanura agrícola actualmente destinada a cultivos de quinua.

Cerrado por un alto acantilado en su parte occidental, el yacimiento está dividido en dos sectores claramente diferenciados, Alto y Bajo Laqaya, entre los cuales se extiende un cinturón de torres chullpas. Las fechas de $\mathrm{C}^{14}$ sitúan su ocupación arqueológica entre fines del siglo XIII y la primera mitad del XV, abarcando Alto Laqaya todo el período, y correspondiendo Bajo Laqaya a la ocupación incaica (Nielsen, 1997: 285-286; 2002: 185). La tradición oral mantiene esta división, tal vez por influencia de los arqueólogos, o quizás no, una cuestión que abordaré en las páginas finales. Por otra parte, si para la arqueología éste constituye el enclave de tradición incaica más importante en la región, para los habitantes de Santiago y Santiago Chuvica, las comunidades vecinas erigidas en custodias del sitio y que rivalizan por su gestión arqueo-turística, Laqaya habría sido la capital de los Lipes en el tiempo de los chullpas, de los antiguos. Ambas interpretaciones resultan igualmente válidas y no excluyentes, pero sí me parece que esta preeminencia concedida a las ruinas de Laqaya por parte de los comunarios marca significativamente el tono de algunas de las reflexiones del pensamiento local acerca del sitio arqueológico y de las historias de ruinas a él referidas, incluidas aquellas que hablan de la guerra antigua. Así por ejemplo, aquí estarían los más importantes capitanes de los auca runas, contra sus muros se dirigiría un gran número de ataques y, por este carácter capitalino, también el asentamiento iba a convertirse en objetivo prioritario de los incas... todo ello al margen de que lo propio siempre se pretenda lo mejor de lo mejor. Y desde esta perspectiva, también Laqaya es el yacimiento a partir del cual ambas comunidades construyen sus expectativas de futuro, ligadas a la explotación turística del yacimiento y a la inserción de Santiago y Santiago Chuvica en los circuitos turísticos que desde Uyuni cruzan el Salar y el Altiplano de Lípez siguiendo la Ruta de las Joyas Altoandinas y que diariamente contratan cientos de turistas para recorrer diferentes salares menores y lagunas salobres para, cruzando la Reserva Nacional de Fauna Salvaje Eduardo Avaroa, conectar con San Pedro de Atacama, en Chile, o retornar a Uyuni (Gil, 2005d).

Reflexionar entonces sobre reflexiones emic acerca de la guerra antigua permite proyectar la clásica oposición barbarie vs. civilización hacia un tiempo más mítico que histórico, y a la vez abordar el concepto de una alteridad pretérita más imaginada que real. Guerra antigua, los antiguos, el tiempo de los chullpas... Pero, ¿qué o quiénes son en realidad estos chullpas, estos antiguos? A grandes rasgos, podría decirse que los chullpas no son nadie y son todos a la vez, porque constituyen la máxima expresión de la alteridad pretérita. Aclararé esto, y para ello empezaré por sintetizar los significados que el concepto chullpa tiene en arqueología, algo que ya traté detalladamente en otras páginas (Gil, 2001). Chullpas son las torres funerarias que se yerguen en el altiplano aymara desde fines del período Tiwanaku (ca. 900-1100 d.C.), y cuya construcción o reutilización se mantiene hasta los primeros tiempos de la Colonia. Pero chullpa es también el bulto funerario depositado al interior de estas torres, aunque hablando con propiedad chullpa es el envoltorio de (digámoslo así para entendernos) dicha momia. En consecuencia, estas relaciones metonímicas provocan que en arqueología andina se llame chullpa a diferentes tipos de enterramientos y sepulcros. De la misma manera, se extiende el término chullpa a ese tipo arquitectónico torriforme, redondo o cuadrado, de piedra o adobe, propio de dicho intervalo temporal, que pudo servir tanto de sepultura como tal vez de depósito de almacenamiento; y para ampliar esta confusión, Guamán Poma habla de chullpa o pucullo para indicar indistintamente en sus dibujos estas torres funerarias y las casas de las gentes primitivas que habitaron su «Segunda Edad de Indios». Y por si esto fuera poco, desde la etnografía se viene a complicar aún más el término. En esencia, chullpa constituye una unidad de clasificación que se aplica a los antiguos presolares. Sin embargo, el concepto implicado es en realidad una categoría abierta que sirve para identificar a todos los antiguos preincaicos en general, equiparándoles así con aquellos que los españoles denominaron los gentiles. Además, desde 
Batallas del pasado en tiempo presente. «Guerra antigua», civilización y pensamiento local en Lípez

una concepción quechua-aymara de la enfermedad, chullpas son las oscuras entidades tutelares que habitan los sitios antiguos, y que inflingen enfermedad a quienes no guardan el debido respeto por los sitios y objetos arqueológicos.

Considerando estos parámetros, se observa que semejante polisemia termina en última instancia remitiendo a dos conceptos básicos: la muerte y el pasado; dos conceptos que son proyectados sobre las ruinas y reconocidos a partir de los restos arqueológicos que en ellas aparecen. Así, por no complicar las cosas, me referiré aquí a los chullpas como sinónimo de los antiguos, apelando entonces a aquellos seres que dentro del discurso local sobre el pasado y sus habitantes constituyeron una otra humanidad que habitó y habita en los chullperíos, en las ruinas, y a partir de la cual se generan, ordenan, e incluso se tratan de controlar, unos espacios y un tiempo paralelos a los de nuestro mundo, pero con el cual se entrecruzan por efecto de la experiencia sensible.

Ruinas y chullpas, chullpas y ruinas, dos caras de una misma moneda, que hacen que no se pueda hablar de unas y otros sin considerar su contraparte. Ahora bien, ihasta qué punto las ruinas y los chullpas, en definitiva, el pasado, es realmente trascendente para los santiagueños? La gente no habla mucho de los chullpas en su vida diaria, pero sus ruinas sí juegan un papel importante en la vida social de Santiago, pues como he apuntado, a partir de la puesta en valor de Laqaya y de su explotación turística, la comunidad está construyendo su ideal de progreso. Pero además, hay otras ruinas o chullperíos, o mejor dicho, parajes con ruinas, que sirven para marcar los límites de la comunidad, e incluso terrenos particulares. En mi estadía de campo en Santiago en 2001, pedí a los alumnos de secundaria y de ciclo intermedio del Núcleo Educativo «Miguel Cuzco» ${ }^{2}$ que me dibujaran su comunidad, buscando con ello establecer un criterio en las pautas de percepción del espacio social entre niños y adolescentes. De 65 trabajos recogidos, 11 incluían la presencia de ruinas o torres-chullpa, que 5 identificaban específicamente con el sitio arqueológico de Laqaya, porcentaje que no deja de resultarme significativo a la hora de analizar la representación del espacio y la elección de sus hitos de referencia.

Por otra parte $-y$ me parece que esto constituye un universal-, las ruinas delimitan un espacio social, infundiendo un temor y un respeto que con los tiempos modernos se han ido perdiendo. Sin embargo, cuando yo empecé a preguntar por la historia local de Santiago, todos los testimonios que obtuve empezaban recurrentemente por la extinción de los chullpas con los primeros rayos solares, y de ahí seguían con el relato de los «modos de vida antiguos» y las referencias a la conquista incaica y la consecuente guerra entre incas y chullpas. Pero curiosamente, como habrá ocasión de comentar más adelante, los santiagueños no se sienten descendientes ni de los chullpas ni de los incas, a quienes consideran protagonistas de otra humanidad, de otro espacio-tiempo de caos previo a la civilización (cf. Gil, 2005a; 2005b). Esto fue lo que me llevó precisamente, desde mi investigación sobre la construcción del discurso histórico local, a interesarme por la guerra antigua y las historias de ruinas.

\section{ETOLOGÍA DE LA VIOLENCIA EN EL TIEMPO DE LOS PUKARAS}

De acuerdo con los principios de la etología, tres son los fundamentos de la violencia: contra los propios congéneres, contra miembros de un grupo de la misma especie (antropológicamente hablando podríamos traducirlo por «cultura» o «etnia»), y contra miembros de un grupo de diferente especie. De igual manera, dos son sus causas principales: competencia por los recursos y competencia reproductora. Así, ante las huellas fosilizadas de manifestaciones de violencia, el arqueólogo se encontrará con dos serios problemas: definir la adscripción intra/interétnica de los implicados, y determinar el carácter del enfrentamiento. Junto a esto, la sombra de un error

2 Desde aquí quisiera expresar mi agradecimiento al cuadro docente de este Núcleo Educativo, y muy especialmente a don Juvenal Choque, su director, por la buena disposición con que siempre ha acogido los talleres y actividades que le he planteado, por su colaboración, y por el tiempo dedicado. 
demasiado común penderá sobre su cabeza: considerando la guerra como un recurso adaptativo, llegar a convertirla en el motor de la historia, ignorando que pueda ser tan sólo una consecuencia más dentro de un contexto de relaciones estructurales más amplio. En consecuencia, la manera de enfocar la guerra y de considerar sus repercusiones histórico-culturales va a depender de cómo se interpreten las causas de la violencia, su frecuencia y su intensidad 3 .

Como señalaba, quizás una de las evidencias más claras de la guerra (o cuando menos de un clima marcado por su amenaza potencial) sería la presencia de fortificaciones, entendidas estas como asentamientos fortificados, refugios fortificados, residencias de élite fortificadas o fortalezas puramente militares. En cualquier caso, además de sus funciones militares, las murallas de cualquiera de los supuestos anteriores proyectan sobre el potencial enemigo un capital simbólico tendente a expresar el poderío del emplazamiento y a disuadirle del ataque (Keeley, 1996: 55-58). Como quedó dicho al principio, las murallas, por sí solas, ya están ejerciendo violencia simbólica.

En el caso andino habría tal vez que diferenciar entre lo que son fortalezas entendidas como esos emplazamientos con funciones estrictamente militares, correspondientes a época Inca, de aquellos otros asentamientos residenciales con propiedades defensivas y protegidos por murallas, característicos de todo el Período Tardío. A pesar de esta distinción, es lo normal referirse a ambos tipos como pukaras (en quechua y aymara, fortaleza, castillo, plaza fuerte), ambigüedad que aquí mantendré en función de su uso en la tradición oral. En cualquier caso, este tipo de emplazamientos queda siempre ubicado en lugares elevados con dominio visual del entorno, una ventaja natural reforzada arquitectónicamente con dificultades de acceso tales como murallas en zigzag provistas de troneras, plataformas y parapetos, ingresos restringidos y controlados, y trazados internos concebidos para facilitar la protección de sus habitantes en caso de que el enemigo lograse superar las defensas anteriores 4.

Por otra parte, recordemos que dentro de la cronología general del altiplano centro-sur, en torno al año $1000 \mathrm{~d}$. C. tiene lugar una profunda reordenación política y territorial marcada por la pugna entre señoríos locales por el control de espacios y recursos. Así, la proliferación de los pukaras revela una complejización social, política y económica supracomunitaria: el miedo a la amenaza y la coerción guerreras harían de la violencia un fomento de la integración política y la concentración de poder, contribuyendo así al refuerzo de las élites locales (Nielsen, 2002: 198199). De esta idea se hicieron también eco las Crónicas de Indias, que, al hilo de la reconstrucción y representación de identidades y agencias derivadas del cambio de orden consiguiente a la conquista española, recogieron una tradición de barbarie previa a la expansión del Tawantinsuyu. Así por ejemplo, Guamán Poma llamó a este período la «Edad de los Auca Runas», el tiempo de los guerreros, de los hombres fuertes, remarcando esta idea de la guerra total:

«Se poblauan los yndios en serros y altos por ser ellos muy fuertes y brabos, que todo su trauajo era guerrear y uenserse unos con otros y quitarse todo quanto tienen en aquel tiempo». (Poma de Ayala, 1987 [1615, f. 66]: 62)

«Estos dichos indios [auca runas] se sallieron y se despoblaron de los dichos buenos citios de temor de la guerra y alzamiento y contradición que tenían entre ellos.

3 Siguiendo el criterio de Keeley (1996) y Guilaine \& Zammit (2002), en lo sucesivo se considerará la guerra en un sentido amplio. Dado que desde la arqueología resulta imposible determinar el carácter del enfrentamiento, y teniendo presente el concepto de «guerra total», estos autores apuestan por incluir dentro de un mismo saco manifestaciones de violencia tan diversas como son las razzias, el pillaje, el choque de dos ejércitos en un campo de batalla, las guerras de conquista/expansión territorial, los duelos entre paladines, el rapto de mujeres, la imposición de tributos por la fuerza, las incursiones en busca de cautivos, las venganzas de honor, las represalias. Además, recordemos que estos conflictos pueden ser a la vez intra e interétnicos, y que su valoración moral y justificación ética varía enormemente de un pueblo a otro.

4 Para un análisis de los pukaras dentro de los patrones de asentamiento prehispánico en Lípez se remite al lector al trabajo de Nielsen (2001: 49-54; 2002: 188 y ss.), donde se comentan en detalle aspectos arquitectónicos defensivos y habitacionales a los que se aludirá en páginas sucesivas a partir de la tradición oral. 
Batallas del pasado en tiempo presente. «Guerra antigua», civilización y pensamiento local en Lípez

De sus pueblos de tierra baja se fueron a poblarse en altos y serros y peñas y por defenderse y comensaron a hazer fortalezas que ellos llaman pucara. Edificaron las paredes y zerco y dentro de ellas casas y fortalezas y escondedixos y pozos para sacar agua da donde beuían.

Y comensaron a rreñir y batalla y mucha guerra y mortanza con su señor y rrey, brabos capitanes y balientes y animosos hombres [...]

Y se quitaban a sus mugeres y hijos y se quitauan sus semejantes y chacaras y asecyas de agua y pastos. Y fueron muy crueles que se rrobaron sus haziendas, rropa, plata, oro, cobre, hasta lleuaron las piedras de moler que ellos llaman maray, tonay, muchoca, callota, y belicosos yndios y traidores». (Poma de Ayala, 1987 [1615, f. 64]: 58-[59]-60)

Otros autores coloniales dibujaron esta misma imagen de un pasado preincaico en pie de guerra. Ya antes que Guamán Poma, Cieza de León había llamado la atención sobre la trivialidad de los enfrentamientos y el dominio de los pukaras en el paisaje, dos puntos sobre los que un siglo después seguía insistiendo el Padre Cobo:

«Había antiguamente gran desorden en todas las provincias deste reino que nosotros llamamos Perú, y que los naturales eran de tan poca razón y entendimiento que es de no creer; porque nos dicen que eran muy bestiales [...]. Sin esto, por los cerros y collados altos tenían sus castillos y fortalezas, desde donde, por causas muy livianas, salían a darse guerra unos a otros, y se mataban y captivaban todos los más que podían». (Cieza de León, 1984 [1553, cap. XXXVIII]:181-182)

«Hacíanse contínua guerra unos pueblos a otros por causas muy livianas, cautivándose y matándose con extraordinaria crueldad. Las ocasiones más frecuentes de sus contiendas eran quitarse unos a otros el agua y campo». (Cobo, 1964 [1653, Lib. XII, cap. I] II: 58)

En tanto que fruto de una tradición oral puesta por escrito en un contexto de conquista y colonización recientes, cabría pensar que la descripción de los Cronistas de Indias responde a un afán manipulador de la historia proveniente del pueblo conquistador-dominante: los incas, unos vencedores vencidos que se presentan a sí mismos como pacificadores y civilizadores de los Andes. Como contrapartida, la arqueología ha venido a desmentir en parte esta idea de la pax incaica; también se ha discutido mucho acerca de la «Edades» de Guamán Poma y su intencionalidad de presentar a los incas como el estadio más perfecto en una evolución cultural y civilizadora dentro del mundo andino (Duviols, 1980; Ossio, 1973, 1976-1977, 1977). Por mi parte, no abordaré aquí estos debates más que como un acompañamiento al pensamiento local de los santiagueños en su reflexionar sobre la conquista incaica de la región. Asimismo, respecto de la (re)presentación de los incas como pacificadores y civilizadores de los Andes, cabe decir que la cuestión no es tanto cómo los incas se construyeron a sí mismos de cara a los españoles, sino cómo construyeron a los otros, lo que al final conduce a un mismo axioma antropológico: la identidad siempre es construida a partir de la representación de la alteridad, del reconocimiento del otro y de las relaciones que se mantengan con él.

En este sentido, lo que me parece interesante aquí son los mecanismos por los cuales el discurso local deconstruye todo este proceso y lo plasma en la memoria. Regresaré sobre esto a su debido tiempo, señalando simplemente en este punto el hecho de que, por un proceso de espacialización de la memoria, la recuperación, revalorización y ensalzamiento de un determinado pasado siempre se lleva a cabo a partir del lugar que éste ocupa en el presente a través de hitos espaciales. En este caso, las ruinas de Laqaya.

Volviendo a la cuestión de las causas de la violencia intergrupal, es de destacar que la tradición oral por mí recogida en Santiago apela a esas mismas causas de competencia por los recursos y de tensión intergrupal que señalaban los autores coloniales a la hora de recrear la guerra antigua.

Don Erasmo Condori Ticona ha sido uno de mis interlocutores más pacientes y detallistas desde que llegué a Santiago por primera vez. Maestro jubilado, encargado del registro civil y parroquial, y sacristán de una iglesia a la que el sacerdote sólo acude cuando se le llama, y 
si puede. Varias veces ha ocupado cargos cívicos y rituales, y hoy es uno de los hombres de prestigio dentro de su comunidad, uno de los que podríamos definir como «guardianes de la tradición, de las costumbres». Pero ante todo, don Erasmo es un gran conversador acerca de los tiempos antiguos y los chullpas. Cuando en una de nuestras charlas le pregunté por las causas de la guerra antigua, esto es lo que me respondió:

«Seguramente ha sido por... Bueno, puede ser por las tierras, más que todo por las tierras de cultivo. Esta gente ya estaba un poco... ¿Cómo se puede decir? Ya vivían en familia; ya no vivían así nómadas, de lugar en lugar, ya eran estables, ya estaban establecidos en un lugar. Entonces, seguramente ellos tenían pues... Porque no eran solos, ese grupo no más; había también más arriba otro grupo, así. Seguramente debe ser por algo de las tierras [...]. Sí, por las tierras de cultivos seguramente peleaban. Algo así tiene que ser. O que venían de repente de otros lugares pues ino? De otros lugares venían, como gente, como guerreros que andaban tal vez peleando. Se cree así más o menos, porque venían otras gentes a atacar, otras gentes. Seguramente de... Puede ser de otras tribus, de otros ayllus, claro. De otras tribus pueden ser. Por eso es que ellos peleaban, porque han sido guerreros». (Erasmo Condori Ticona, 60 años. 2002)

Por su parte, don Justino Calcina Lupa, mi compadre, podría decirse que es un experto local en Laqaya, uno de los primeros en mirar el sitio arqueológico desde la perspectiva del turismo. Junto a don Erasmo y otros comunarios de Santiago y Santiago Chuvica, fue uno de los motores, allá por 2000, del Comité Impulsor de Turismo, y es uno de los principales activistas del actual Comité Impulsor del Parque Laqaya. Con él he conversado mucho sobre el presente y el futuro de sus ruinas, que en múltiples ocasiones hemos recorrido juntos; unas veces escuchando sus relatos sobre el tiempo de los chullpas, otras, discutiendo aspectos relacionados con el turismo y la promoción turística del yacimiento, o simplemente, charlando de cualquier cosa. Ésta es su versión de las circunstancias que habrían avocado a los antiguos a ese estado de guerra total:

«Se supone que ellos han peleado por tierras, o por ojos de agua, o por más animales nativos que habían.

Como por decir: aquí estaban habitando los chullpas, y después venían de otros pukaras, o de otras partes, como ser los Urus, y después hablamos de la gente atacameña. Todo ello. Entonces, por este sector hay muchos ojos de agua; bueno, también hay muchas peñas, muchas rocas. Entonces, ahí es donde habitaba más la chinchilla, la vizcacha, el amo, todos estos animales. Entonces, bueno, también era... digamos... tal vez entre pueblos, o entre nómadas se puede decir, o tribus se puede decir. Bueno, habían otros conflictos por mujeres, que se quitaban las mujeres el uno al otro. Entonces ellos se han reunido aquí [en Alto Laqaya]. [...]. Aquí estaban ellos ya concentrados en esa época de guerra». (Justino Calcina Lupa, 41 años. 2002)

Desde esta perspectiva, las Crónicas de Indias y la tradición oral de los santiagueños coinciden en recrear una imagen del pasado (preincaico) en permanente pie de guerra. En una situación de profundos cambios generales en las sociedades y los espacios altiplánicos, es como si las razzias guerreras de distinto calibre estuvieran a la orden del día; razzias protagonizadas por grupos de guerreros que buscarían tanto la obtención de un botín como el debilitamiento de los vecinos. Y en este sentido, al igual que la interpretación arqueológica y el relato de los Cronistas de Indias («por ser ellos muy fuertes y brabos», decía Guamán Poma - vid supra), también la tradición oral parece apoyarse en la idea de un reforzamiento de las élites como causa-efecto de estos conflictos interétnicos; en el decir de don Justino:

«Por convulsiones sociales, por algunos problemas con otras tribus o con otras manadas de personas, estos chullpas... bueno, han ido fortaleciéndose aquí, en este sitio de Alto Laqaya. Entonces... bueno, ellos tenían los capitanes, los que comandaban. Ellos se llamaban los Auca Runas. ¿Qué significa los Auca Runas?: 'hombres fuertes', 'guerreros', bueno, donde ellos hacían la guerra cuerpo a cuerpo». (Justino Calcina Lupa, 41 años. 2002) 
Prestando entonces atención a esta expresión de las causas de la guerra, fijémonos en un aspecto que me parece destacable: que al margen de la lucha por los recursos y de las tensiones intergrupales, tal como había apuntado don Justino, «habían otros conflictos por mujeres, que se quitaban las mujeres el uno al otro» (vid supra). En relación a ello, recordemos que los soldados incas podían retener a las mujeres que capturaban en combate, y que además los más valerosos guerreros podían recibir acllas ( «Vírgenes del Sol») por esposas como recompensa (Rowe, 1963 [1946]: 279-280). Ya más próximo al presente, hay también constancia de que en el curso de algunos tinkus («batallas rituales») las mujeres asistentes pueden ser capturadas y ocasionalmente violadas; suele tratarse de mujeres solteras que en muchas ocasiones terminan por contraer matrimonio con sus captores (Gorbak et al., 1962: 250, 258; Platt, 1986: 240). En realidad, no se trata sino de maneras de ligar guerra y matrimonio ${ }^{5}$. Tengamos la idea presente cuando más adelante mis interlocutores comenten que la vida de la mujer era la única respetada en el fragor de la batalla. iY si parte de las guerras pretéritas correspondiera en realidad a estas «batallas rituales», con un enfrentamiento pactado de los contrarios? iY si algunas de ellas se organizaran con el pretexto de intercambiar mujeres? Lamentablemente, ni la etnohistoria ni la antropología pueden establecer más que conjeturas al respecto.

Más allá de esta cuestión del rapto de mujeres (¿causa o consecuencia de razzias?), y a tenor de la lectura general, pareciera que la tónica se reduce al enfrentamiento contra comunidades de grupos étnicos distintos, presentándose los pukaras como lugar de refugio para los momentos de conflicto; plazas fortificadas a las cuales la gente de las comunidades cercanas acudiría a protegerse del ataque más o menos recurrente de estos grupos rivales. Lo cierto es que esta idea acerca de la funcionalidad de los pukaras constituye todavía un debate abierto en arqueología ( $v$.gr. Nielsen, 2002; Topic \& Topic, 1997), razón de más para no entrar aquí a cuestionar al pensamiento local su particular visión de los hechos. En cualquier caso, ¿̇e qué manera se desarrollarían los enfrentamientos, cómo habría sido una de aquellas batallas de los tiempos remotos?

\section{RECREANDO LA BATALLA: UN SUPUESTO ATAQUE CONTRA LAQAYA}

Recordemos lo descrito acerca de la topografía del sitio de Laqaya y de su división en dos sectores claramente diferenciados, y a continuación dejémonos llevar por esas historias de ruinas que hablan de cómo se habría llevado a cabo un ataque contra los muros del pukara de Alto Laqaya. Más allá de lo que su arquitectura permite inferir, el único testigo material de violencia que la arqueología ha podido registrar aquí es un número abundante de puntas de proyectil dispersas por el perímetro de su doble muralla. Así, cederé la palabra al pensamiento local para tratar de reconstruir un supuesto asalto.

En uno de nuestros paseos entre las piedras de Laqaya, mezclándolo con los recuerdos de aquel día en que de niño tardó horas de angustia en escapar de lo que para él era entonces un terrible laberinto de ruinas, don Justino me ofreció la siguiente interpretación sobre la arquitectura defensiva del pukara:

«Tenemos el primer muro defensivo, con ventanillas expuestas a todo lugar. $\mathrm{Y}$ hay unas pequeñas murallas dentro del primer muro defensivo; entonces, eso se supone que eran unas trincheras, etc. ¿no? Y después pasamos — que se ve al centro también—al segundo muro defensivo, que obviamente es un poco más alto que el primer muro defensivo

5 Apoyándose en la etnografía de las sociedades amazónicas, Lévy-Strauss (1943) ya llamó la atención sobre este aspecto al señalar la alianza matrimonial como salida a la guerra y multiplicación de las relaciones sociales. Por su parte, Clastres (2001 [1977]: 194 y ss.) planteó una crítica al modelo levy-straussiano, discutiendo ampliamente si la guerra es el resultado de una alianza mal resuelta, o si la alianza se produce como solución para el fin de una guerra. A este respecto, resulta igualmente destacable el trabajo de Camino (1977), donde se analizan la guerra y el intercambio de mujeres entre los Andes y las Tierras Bajas como parte de la construcción del otro y las formas de interactuar con él. 
¿no?, y con muchas [más] ventanillas que el primer muro defensivo. Entonces, eso era donde se atrincheraban para defenderse. [... los enemigos] podían pasar el primer muro defensivo, pero no ya el segundo [...]. Pasando el segundo muro ya están las habitaciones ya construidas. También... ¿cómo se dice?... esencialmente con una estructura muy especial. Las puertas están vistas a un solo lado, y hay como unos laberintos, calles muy chiquititas que es... sirven como pa perderse. [...]. Sí, el enemigo pasaba el primer muro defensivo, pero ya no podía pasar el segundo muro defensivo, ni mucho menos aquí, a las habitaciones». (Justino Calcina Lupa, 41 años, 2002)

Mis entrevistas con don Erasmo siempre han tenido lugar por la tarde, coincidiendo con ese lapso de tiempo (de 19 a 21 horas) en que un generador alimentado con diesel permite a los santiagueños disfrutar la electricidad. En una ocasión en que veníamos tratando la arquitectura doméstica y el patrón de asentamiento de los antiguos, la conversación derivó hacia la arquitectura defensiva de los pukaras y el carácter guerrero de los chullpas:

«En Alto Laqaya se ve la muralla defensiva que tenían los chullpa, la gente antigua. Entonces yo creo que ha sido el medio de defensa de ellos ino?, porque [son] dos muros que se nota ciertamente que tienen unas ventanitas, donde el centinela seguramente de ese tiempo estaba. En esas ventanitas observaban ino?, si el enemigo se acerca y algo pasa ¿no? Seguramente. Y esa era la parte donde ellos ya podían estar poniéndose alerta ¿no? Si es que un enemigo se acerca... Bueno, eran para eso esas ventanitas, para eso. Justamente se cree que ha sido esa gente guerrera más que todo, porque ahí se encuentran flechitas. Hay flechitas. O han sido cazadores, también se puede decir, como vivir de la caza. Más que todo yo creo que han sido guerreros, porque de eso se cree de que para eso han hecho la muralla defensiva, porque si no fuera esa muralla, el enemigo se entra por cualquiera parte. Entonces no podían fácilmente trastornar la muralla; seguramente ellos ya esperaban con flechas, y desde esos agujeritos ellos atacaban a sus enemigos. Por eso decimos que esa gente eran guerreros». (Erasmo Condori Ticona, 60 años, 2002)

Alto Laqaya, su doble muralla y dos testimonios que les dedican especial atención. Todo ello permite hablar de dos aspectos significativos de la arquitectura defensiva del pukara: la presencia en estos muros de «ventanitas» desde donde vigilar y repeler el ataque, y la organización del espacio intramuros y su relación con la existencia de una élite guerrera. Refiriéndose a dichas «ventanitas», don Erasmo apunta que los defensores «esperaban con flechas, y desde esos agujeritos ellos atacaban a sus enemigos», pero lo cierto es que este planteamiento presenta algunos fallos tácticos y técnicos. En primer lugar, porque estos vanos se sitúan a media altura de unos muros que en la actualidad no superan el metro y medio, de tal manera que su ubicación no parece la más idónea para un observatorio de vigilancia como consecuencia del reducido ángulo de visión que desde ellos se obtiene. A pesar de ello, para el pensamiento local este punto no supone problema alguno, ya que, como abordaré enseguida, tampoco los chullpas alcanzaban una altura demasiado elevada.

Por otro lado, y atendiendo a su forma cuadrada, más difícil resulta la idea de que a través de ellos se disparasen flechas, un dato que también apunta Nielsen (2002: 187) al describir el pukara de Cruz Vinto (aproximadamente a $20 \mathrm{~km}$ al NE de Laqaya) y registrar «vanos semejantes a "troneras", desde donde los ocupantes del sitio podrían avistar al enemigo sin necesidad de exponerse y disparar con arcos y flechas». A la luz de los hallazgos arqueológicos, no cabe duda de que los antiguos pobladores del Altiplano de Lípez utilizaron el arco y la flecha6, ya fuera para la caza o para el ejercicio de la guerra, como apuntan las puntas de flecha encontradas a los pies de las murallas de Laqaya. Sin embargo, más dudoso resulta pensar que a través de estos vanos pudieran ejecutarse disparos con arco, tanto por la posición que debería adoptar el arquero, como por las

6 Destacan a este respecto el carcaj de cuero de vicuña con quince astiles de flecha hallados en una tumba del sitio Mallku Abajo por Arellano \& Berberián (1981: 56), así como los astiles de flecha encontrados por Arellano (2000: 190-191, 209-210) en el sitio Soniquera ST-065, facturados en bambú delgado y algunos de ellos con puntas de madera. En ambos casos, dichos astiles presentaban un tipo de decoración geométrica que recuerda mucho a los registrados en el norte de Chile. 
posibilidades tan reducidas de dirección y ángulo de tiro que desde éstos se alcanza. Por lo mismos motivos, tampoco parece factible que los defensores del pukara se sirvieran de estas aberturas en el muro para lanzar con honda, a pesar de que en el citado sitio de Cruz Vinto se hayan encontrado acumulaciones de proyectiles por el lado de dentro de la muralla junto a estos vanos. En cualquier caso, más interesante que la discusión funcional de estas «ventanitas» resulta el hecho de que don Erasmo atribuya a los antiguos el uso del arco y la flecha para el arte de la guerra, dato que, como discutiré más adelante, queda estrechamente ligado a la caracterización de los chullpas como una alteridad salvaje desde la perspectiva de un choque de civilización.

Fijémonos ahora en ese mencionado segundo aspecto significativo derivado de los testimonios de don Justino y don Erasmo, la organización del espacio intramuros y su relación con la existencia de una élite guerrera. Este último nunca me ha acompañado en mis paseos por las ruinas de Laqaya, aunque el poder de evocación de su plática hace que muchas veces las hallamos recorrido juntos. En una ocasión, conversando sobre su patrón de asentamiento, establecía las siguientes diferencias en su reconstrucción de Alto y Bajo Laqaya:

«[Las murallas] han sido el medio de defensa de ellos, para que no se entren los enemigos fácilmente, porque lo hay en cada parte; como a diez metros, ni eso ino?, ni a diez metros creo que hay [una muralla] distinta. Entonces tienen unas puertas de entrada; simplemente hay dos puertas de entrada, grandes, y una de salida que está al otro lado, para ir a Bajo Laqaya ino? Entonces es que nosotros vemos que han sido murallas defensivas, que tenían dos murallas defensivas. Una es la más grande, que está más lejos, y el otro está más cerca y es más corta. Seguramente ahí arriba nosotros detectamos que habría sido el rey, en Alto Laqaya; ahí estaría el jefe. Así se nota de acuerdo a las viviendas que tienen; entonces tienen algunas divisiones, generalmente son más... ¿cómo se puede decir?... un poco más arregladas, o que tienen más divisiones. También el jefe puede estar con sus centinelas, su secretaría, que se puede decir así; tienen más habitaciones, que tienen sus pasadizos, sus callecitas. Creo que ha sido eso, que el jefe estaba ahí, y por eso que como centinelas se empleaban ino?, en la parte de arriba. En la parte de abajo ya no es así, seguramente otra gente estaba. Se cree que en las casas que tienen, todas están con vista a arriba. Seguramente entonces que la gente estaba ya a la expectativa para cualquiera cosa ino? Con vista ahí arriba, cualquiera cosa que haya... Entonces están mirando ahí, con vista hacia arriba. Entonces eso significa que toda la gente que estaba ahí abajo tenía que estar mirando, con sus casitas con vistas a arriba, para ver si hay alguna seña, alguna alarma. Entonces ellos ya inmediatamente se ponían a las armas, para reforzar, o para... Claro, seguramente ha sido eso ino?, porque es según lo que vemos, detectamos: que esa gente ha sido guerrera, guerrera ha sido». (Erasmo Condori Ticona, 60 años, 2002)

Ya comenté que don Erasmo fue uno de los miembros fundadores del Comité Impulsor de Turismo para Laqaya, y por su posición dentro de la comunidad está plenamente al tanto de las labores de prospección y excavación en el yacimiento. Por este motivo pudiera resultar paradógico el hecho de que obvie en esta explicación la cronología arqueológica y haga coincidir en un mismo plano espacio-temporal a los dos sectores diferenciados de Alto y Bajo Laqaya, relacionando el poblado de época incaica como el pueblo, y considerando el pukara como la residencia de las élites y lugar de refugio de toda la población en momentos de peligro. Retomaré este detalle al momento de plantear la discusión de hasta qué punto los santiagueños están influenciados por el discurso arqueológico a la hora de construir su representación del pasado y sus habitantes a partir de las ruinas.

Volviendo al recinto amurallado y a las descripciones hechas por don Justino y don Erasmo, dos muros defensivos antes de acceder al conjunto habitacional del pukara. Según lo hasta aquí comentado, en él no sólo encontrarían refugio familias completas en momentos de peligro, sino que además, según añade don Justino, el pukara serviría también

«...como el palacio del presidente, como del rey podemos decir. Desde aquí estarían comandando ya los Auca Runas la guerra». (Justino Calcina Lupa, 41 años. 2002) 
Expresado en otros términos, el corazón del pukara representaría el baluarte del alto mando sociopolítico y militar, un bastión a proteger a toda costa en el transcurso de la batalla. Tal vez por este motivo, y aunque la arqueología no lo constate, las historias de ruinas hablan de tres túneles secretos por los que huir en caso de necesidad, y/o a través de los cuales escurrirse en busca de avituallamiento durante el asedio. Uno de estos túneles —el único que, con notable ejercicio de imaginación, podría intuirse - pone en contacto el pukara con Bajo Laqaya a través del cinturón chullpario; los otros dos saldrían justo al borde del acantilado, donde hoy brota un ojo de agua. La tradición oral andina está plagada de relatos que describen mundos subterráneos (o, con más propiedad, de adentro) recorridos por laberínticos túneles que atraviesan los cerros y en los que habitan sus dueños, o que corren por debajo del Titicaca interconectando el eje acuático altipánico, o que esconden tesoros y riquezas minerales. Sin embargo, la explicación que don Justino me dio de estos túneles resultó meramente táctica:

«Claro, ellos se hacían muy estratégicos también. Entonces estos túneles... Se hacían llegar con agua, y directo a este túnel se escapaban. [...]. Entonces, también, desde esos túneles, avistaban al enemigo también, porque cualquier enemigo, cualquiera venía por la guarida de las rocas y, bueno, podría penetrar aquí donde estaban atrincherados». (Justino Calcina Lupa, 41 años, 2002)

Pensando en el asedio, y combinando la (supuesta) existencia de estos túneles con la necesidad que habrían tenido los habitantes de Laqaya de seguir proveyéndose de agua y alimentos para resistir, don Justino prosigue:

«Lo que contaban los abuelos, nuestros abuelos, era que cuando se hacían guerras, combates, al que más respetaban era una mujer; y de aquí mandaban a Ojitos de Laqaya ${ }^{7}$, donde hay agua. Entonces solamente mandaban niñas a que trajeran agua, para que se provean, porque el enemigo respetaba a la mujer y no lo torturaba ino?, y mientras lo veía a un niño, a un hombre... bueno, lo torturaba ino? Eso es lo que contaban los abuelos ino?, y por eso decían que hay que respetar a la mujer, etc. Pero siempre estaban avisados. Seguramente las niñas iban a recoger agua para el alimento.

Eh... bueno, se supone que las raptaban también ino? Las mandaban en horarios muy controlados, donde no habían enemigos en ese momento, o la guerra terminaba y es que terminaban los hombres matando. En ese momento, ya cuando pasaba, mandaban a las niñas. Igual, digamos, en otros lugares también cuentan que siempre iban las niñas a recoger agua, por provisión de alimento». (Justino Calcina Lupa, 41 años, 2002)

Recordando lo señalado anteriormente acerca del rapto de mujeres, la guerra y el matrimonio, ¿por qué no pensar que no es que los chullpas respetasen a la mujer de manera modélica, sino que esta estaba considerada como un botín de guerra digno de ser protegido por parte de los suyos?

Tácticamente hablando, esta reconstrucción de un supuesto ataque al pukara de Laqaya hecha por mis interlocutores resulta más que verosímil: doble muralla defensiva, baluarte para las élites y el mando militar, salidas secretas para el abastecimiento o la huida... Quizás el único punto débil de sus interpretaciones gire en un aspecto ya comentado: la efectividad para la defensa de esos muros que, por su altura, debieran considerarse más bien como parapetos. Por un lado, ascender hoy por el sendero interpretativo que recorre el yacimiento desde la base de la colina hasta los muros defensivos implica cierta dificultad a causa del desnivel. Asimismo, tratar de alcanzar directamente la parte alta de las ruinas a campo travieso resulta aún más difícil como consecuencia de la naturaleza del terreno. En consecuencia, tratemos de imaginar a un grupo de guerreros que, pertrechados con toda su panoplia, tratan de romper desde abajo la defensa de los de arriba. Por una cuestión meramente topográfica, la empresa, sin duda, se representa complicada, más aún teniendo en cuenta que hablamos de ejércitos carentes de maquinaria

7 Al referir estos «Ojitos de Laqaya», mi compadre don Justino señala en la dirección del ojo de agua remansado que se sitúa un poco más allá del yacimiento de Laqaya, en la punta del morro de ese mencionado acantilado que cierra el sitio por su parte occidental, el lugar donde se ubica el rancherío de doña Catalina, vecina de Santiago Chuvica. 
de guerra. Pero por otro lado, habría que reconsiderar que tampoco hablamos de elevadas y robustas murallas comparables a las de los castillos medievales, sino más bien de muros de metro o metro y medio de altura y delgado espesor, más parecidos a una pirca más gruesa de lo habitual que a una verdadera muralla.

Por lógica táctica, estos muros habrían sido siendo levantados, amparados en la topografía, como parapeto de los defensores y obstáculo contra un cuerpo atacante que llega corriendo cuesta arriba y bajo una lluvia de flechas y hondadas, cumpliendo así una función similar a la de taludes, fosos o campos de piedras hincadas propios de otros contextos históricos de la antigüedad y el medioevo del Viejo Mundo. Sin embargo, para los santiagueños son auténticas murallas, y despiertan en ellos una admiración tal hacia sus constructores que les lleva a reflexionar acerca de la naturaleza de los antiguos. Resultado: como ya se apuntó más arriba, los chullpas eran enanos dotados de una fuerza descomunal. Así los describió don Justino cuando, en una de nuestras visitas a las ruinas, le llamé la atención sobre esta cuestión de la escasa altura de los muros defensivos y mis dudas sobre su efectividad:

«[Las murallas] son bajitas porque... bueno, esa gente era también muy pequeña. Entonces también a la altura de la estatura así lo han hecho, porque si venían los guerreros... Bueno, son ventanillas para ver, o para avistar al enemigo... Entonces, bueno, de alguna manera ellos se defendían y no dejaban pasar el muro». (Justino Calcina Lupa, 41 años, 2002)

Y después de comentar otras cuestiones tácticas ya recogidas en estas páginas, y ante mi insistencia incrédula, prosiguió:

«[Los chullpas] eran hombres fuertes, que tenían mucha fuerza ino? [...]. En cualquier parte, los chullpas siempre han alzado piedras grandes que ahora nosotros no lo podemos, y eso demuestra que su... en su... ¿cómo se dice?... en las momias, que eran personas siempre pequeñas. Pero siempre toda construcción que han hecho, toda arquitectura, que se puede decir, están construidos con piedras grandes ino? Y quizás que estas piedras [de Laqaya] son pequeñas, pero en otras partes hemos visto, digamos, piedras más grandes y [muros] expuestos a una altura de un metro cincuenta; naturalmente que nosotros ahora no podemos construirlo así». (Justino Calcina Lupa, 41 años. 2002)

Como queda patente en esta alusión a las momias, el pensamiento local calcula la altura de los chullpas a partir de una relación metonímica que relaciona directamente la imagen recreada de los antiguos con las dimensiones de esos cuerpos momificados de manera natural que aparecen al interior de las torres chullpa. En razón de ello, dado su tamaño y el volumen de piedra empleado en las murallas, don Justino considera a los chullpas como «hombres fuertes, que tenían gran fortaleza». Sin embargo, también habría otra explicación para ello, una que considera a los chullpas como una raza de naturaleza no del todo humana, enanos dotados de poderes mágicos para mover sin esfuerzo las piedras.

Wilson Condori Vilca es hijo de don Erasmo, y vive a caballo entre Santiago y la ciudad de Uyuni, donde pasa cada vez más tiempo por motivos laborales; pero a pesar de la distancia, es buen conocedor del territorio que rodea a su comunidad, y me guió en muchos de mis paseos arqueológicos durante aquella primera visita a Santiago en 2001. En una ocasión, recorriendo las ruinas de Chorco y Escócales, dos chullperíos ubicados en la falda del Cerro Karal Inca (el otro mallku de la comunidad), me ofreció esta explicación acerca de cómo construirían los chullpas:

«A la piedra le decían que se subía... entonces se subía, seguramente. La piedra se movía y entendía más que la gente. La piedra, cuando le decían "rodar", rodaba, dicen, de por sí, sin que la lleven. "iSubíte encima!" La piedra entonces se subía, también dicen». (Wilson Condori Vilca, 29 años. 2001) 8

8 Contrastaría esta buena disposición de las piedras al movimiento por orden de los chullpas con esos otros relatos de tradición incaica que hablan de «piedras cansadas», que se niegan a continuar su traslado y quedan fijadas al paisaje, estableciendo así desde su emplazamiento un discurso lítico de importancia cosmológica. Para un análisis general de estas «piedras cansadas» y su discruso, cfr. Guchte, 1984. 
Así pues, hay cualidades fabulosas que se añaden a la caracterización de los antiguos como hombres fuertes entregados a la guerra, a una guerra que, en palabras de don Justino,

«[...] era... digamos... no me explico mucho, pero por lo que hay el primer muro defensivo y luego por lo que hay el segundo muro defensivo, la guerra ha debido ser muy campal». (Justino Calcina Lupa, 41 años. 2002)

Pero la batalla no ha terminado todavía. Primero, en todo enfrentamiento $-\mathrm{y}$ aunque nos empeñemos en decir lo contrario - siempre hay un vencedor y un vencido; segundo, también se dice — y debe ser verdad — que la guerra saca lo mejor y lo peor que cada uno de nosotros llevamos dentro. Entonces, ¿cómo terminaría este supuesto asalto a Laqaya? Y otra cuestión, ¿qué otros rasgos de la naturaleza de los chullpas pueden descubrirse a partir de su comportamiento violento?

Sin penetrar demasiado en el concepto de persona aplicado a los chullpas —algo que ya desarrollé en otra ocasión (Gil, 2005a)—, sí mencionaré que si hay algo que caracterice a un salvaje tanto o más que la desnudez — sobre lo que volveré al considerar la supuesta civilización de los chullpas por parte de los incas — son sus hábitos alimenticios, que en el civilizado suelen provocar cierta repugnancia. Aplicando aquel triángulo lévy-straussiano crudo-cocido-podrido al pensamiento andino y a sus maneras de mesa, comer sin sal ni ají corresponde al salvajismo de los gentiles, mientras que se trata de dos elementos que no pueden faltar en la dieta de los cristianos, de los «verdaderos seres humanos» (Spedding, 1993: 58-59). Sin embargo, si hay una práctica culinaria por excelencia que caracterice al salvaje, al bárbaro, que denigra al otro, ésa es el canibalismo (Bartra, 1997: cap. 4). Pues bien, además de comer sin sal, parece que en cierto sentido los chullpas eran también antropófagos, algo que, en el decir de don Justino, les distancia de los santiagueños por lo que a humanidad se refiere:

«Entonces [los chullpas] vivían en una vida de herejía, o sea que eran herejes, que no eran cristianos; que a veces entre ellos se comían, que a veces se le comían al más flojo. Bueno, etc.: que comían también carne humana». (Justino Calcina Lupa, 41 años, 2002) Después de conocer este dato no resulta muy difícil imaginar qué final se prevé reservado a los vencidos. Don Justino prosigue:

«Se trituraban entre ellos. Ellos se trituraban. Mataban un enemigo, entonces ellos lo trituraban; los huesos lo quemaban, y después, luego, los huesos lo molían, dice, lo molían y lo hacían llevar con el viento. Y eran seguramente personas muy... sumamente salvajes». (Justino Calcina Lupa, 41 años, 2002)

En este sentido, el tratamiento dado por los chullpas a sus enemigos vencidos recuerda bastante a lo apuntado por el cronista Guamán Poma al describir la «Edad de los Auca Runas» y la condición moral de aquellas gentes:

«De cómo mandaua y eran muy belicosos yndios y brabos guerreros y fuertes: Cada uno de ellos se enbestían como leones y ci le mataua al contrario, le sacaua el corasón y lo comían de puri brabo y fuerte guerrero y capitán». (Poma de Ayala, 1987 [1615, f. 66]: 62)

Por más que pudiera relacionarse el canibalismo como una consecuencia más del primitivismo de los antiguos, lo cierto es que las prácticas de antropofagia en el contexto de la guerra constituyen la mutilación más extrema que puede darse a un enemigo, cuestión que remite directamente a la concepción de la persona y a la asimilación/destrucción de la alteridad. Guamán Poma nos sitúa ante un modo de incorporación del coraje y la fuerza del enemigo a la propia persona del guerrero victorioso a partir de la ingesta de su corazón. En este sentido, lejos de implicar su desintegración física, la práctica del canibalismo ritual sobre porciones concretas del cuerpo del contrario a las que se atribuyen ciertas cualidades/poderes representa también el mecanismo de apropiación de sus cualidades guerreras, de su valor ${ }^{9}$. Sin embargo, el testimonio

9 Cabe señalarse que este mecanismo de apropiación del enemigo mediante el canibalismo ritual sería el mismo que rige el culto a las cabezas trofeo, una práctica muy extendida entre sociedades tribales de África, Asia y Sudamérica, incluido el mundo andino aunque aquí no se refiera. 
de don Justino no habla de incorporación sino de una aniquilación total del enemigo en los diferentes planos espacio-temporales; de ahí que el enemigo sea reducido a cenizas y esparcido al viento10. De la misma manera, esta práctica de reducir al otro a cenizas que se esparcen al viento resulta totalmente coherente con el concepto andino de persona: para poder acceder a la vida post-mortem, el cuerpo del individuo debe permanecer íntegro11. Pulverizar al enemigo no supone entonces simplemente su desintegración física en el espacio, sino que además lo elimina definitivamente del plano (a)temporal y de la memoria, le impide el acceso a la otra vida y niega a sus descendientes la posibilidad de proyectar sobre él las prácticas del culto a los antepasados. Así, de un modo u otro, lo que a priori pudieran parecer simples aditamentos a una descripción peyorativa de los chullpas en tanto que salvajes bestiales, responden en realidad a la perviviencia - al menos en la tradición oral — de una racionalidad cultural andina anclada en otros tiempos y otros principios.

Llevando todas estas cuestiones del presente al pasado, y expresado en términos de construcción de la alteridad pretérita, retomaré una conclusión ya expresada páginas atrás: que los chullpas constituyen ese salvaje que todo pueblo, toda cultura, necesita proyectar más allá de sus fronteras espacio-temporales para auto-afirmarse como auténticos seres humanos civilizados ${ }^{12}$. Desde esta perspectiva, atendiendo a que en la idea de la violencia se mide también la idea del otro, será más fácil entender la lógica operante detrás de la filosofía que rige una apología del imperialismo tan repetida a lo largo de la historia: la civilización de los pueblos bárbaros, un proceso que, en opinión de Bartra (1996: 218), ha implicado históricamente la construcción cultural fundada de un corpus mitológico que sirva de soporte a la propia identidad de los autodenominados pueblos civilizados. Así, que los pueblos habitantes de los límites del Tawantinsuyu fueran unos salvajes en continuo estado de guerra es lo que legitimaría esa llamada pax incaica: por medio de la guerra de conquista, integrarlos a la civilización (Cerpa, 2001: 181-201, 371-396).

\section{LA BATALLA CONTRA EL OTRO. GUERRA Y CIVILIZACIÓN CON LA LLEGADA DE LOS INCAS}

Desde que Hobbes afirmara en su Leviatán (1651) que la guerra de todos contra todos constituye la condición natural de los seres humanos, muchas páginas se han escrito discutiendo acerca de si la violencia es un comportamiento natural o social, reflexionando acerca de una llamada «guerra primitiva»13. No entraré aquí en este debate, tan propio de la antropología filosófica, ni tampoco en aquel que discute si el progreso de la barbarie a la civilización ha de discurrir inexorablemente por el camino de la guerra. Por el contrario, sí tomaré en cuenta la máxima

10 A este respecto de la reducción del enemigo a cenizas y su esparcimiento como mecanismo de aniquilación total del enemigo, nótese una diferencia clave frente a prácticas de canibalismo ritual practicadas por distintos grupos amazónicos y asiáticos que, mezclándolas con determinadas bebidas, ingieren las cenizas tanto de sus parientes fallecidos como de sus contrarios vencidos, una manera de incorporar así a la propia identidad las cualidades de la persona de los otros (cf. Fausto, 2002).

11 En otro trabajo ya abordé la importancia de los bultos funerarios y el culto a los antepasados en relación a esta cuestión de la integridad post mortem de la persona y al manejo del tiempo en el mundo andino (Gil, 2002). Referido a este punto de la reducción del enemigo a cenizas y la destrucción de su alteridad, valga como ilustración del daño que se puede ejercer a la persona al reducirla a cenizas el caso del último Inca, Atahualpa, que se bautizó en los momentos previos a su ejecución a fin de conmutar la muerte en la hoguera por la pena de garrote. No solo mantenía así la integridad corporal de su persona, sino que en consecuencia, y por gracia de su padre el Sol, prometía además a los suyos regresar convertido en serpiente vengadora del agravio que los españoles estaban infringiendo a su pueblo (Cieza de León, 1986 [1550-1954, cap. LIV]: 188).

12 Para un documentado y prolijo análisis e interpretación de esta cuestión en distintas culturas y sociedades, desde la antigüedad clásica hasta prácticamente nuestros días, remito al lector a los dos trabajos de Bartra $(1996 ; 1997)$ citados en la bibliografía.

13 A este respecto, consultar los trabajos de Clastres $(1974 ;$ 2001) y Keeley (1996), donde se establece una revisión crítica en torno a diferentes posturas sobre este concepto de «guerra primitiva». 
de que «violencia engendra violencia» como telón de fondo sobre el cual proyectar esa tan cacareada idea de la pax incaica desde la perspectiva del pensamiento local, y con las ruinas de Laqaya como escenario de la guerra entre los chullpas y los incas. ¿Constituye la guerra el fundamento de la evolución hacia un Estado que garantice la paz (Hobbes)? O más bien ¿deriva de una resistencia contra un Estado que viene a corromper el mundo del «buen salvaje» (Rousseau, Clastres)? En cualquier caso, es un hecho histórico que las pacificaciones por la fuerza suelen lograr un efecto contrario al deseado, en tanto que generalmente devienen en trabajos forzados, pérdidas territoriales, explotación económica, subordinación sociopolítica, esclavitud. Por lo que a Laqaya se refiere, podría decirse que la tradición oral de los santiagueños está bebiendo (más que seguro, sin saberlo) de ambas corrientes filosóficas para explicar lo que ocurrió con los chullpas a la llegada de los incas.

En términos históricos, todo el sector norte de Lípez jugó un papel destacado en la economía y la geopolítica del Tawantinsuyu. Desde esta óptica, ubicado justo en la zona de mayor potencial agrícola de todo el sector, el sitio de Laqaya habría sido uno de los enclaves esenciales dentro de la organización regional incaica. Como otros emplazamientos de características similares en su entorno, se piensa que Laqaya constituiría una comunidad tributaria del incario a partir del laboreo en los campos del Estado y/o la extracción de metales y sal, además de constituir un nexo en las rutas caravaneras que unían los centros de Nor Lípez con la región del Loa Superior, en el norte de Chile (Nielsen, 1997: 285-286). Ahora bien, dicho esto, ¿qué (se dice que) pasó cuando los incas llegaron a Lípez? ¿Cómo reaccionaron los chullpas? Como se apuntó, pros y contras. Conversando con don Justino sobre este punto, primeramente haría hincapié en el empuje pacificador y civilizador paralelo a la expansión del Tawantinsuyu, considerando entonces la pax incaica en su vertiente positiva:

«Cuando estaban en plena guerra, ya llegarían los incas a colonizar por aquí. Los incas se expandían por el lago Titicaca, y así por toda la tierra de los Lipes, así a Atacama en Chile, como al norte de Argentina ino? Y bueno, ya prácticamente cuando estaban así los chullpas en guerra, han llegado los incas a colonizar, y ellos son los que han hecho dejar el paz, o sea, los que han hecho vivir en paz. Y, naturalmente, ellos han llegado y, bueno, los han enseñado otras cosas, muy buenas». (Justino Calcina Lupa, 41 años. 2002)

Efectivamente, la pax incaica prohibía cualquier enfrentamiento armado entre los grupos incluidos dentro del Tawantinsuyu, convirtiendo la agresión interétnica en motivo más que suficiente para poner en marcha una campaña de «pacificación». Y con la pacificación, la «civilización». Para empezar, al cesar el clima de guerra total perdería su razón de ser la arquitectura defensiva de los pukaras, de manera que con los incas llegaría también un cambio en los patrones de asentamiento. En el caso particular que nos ocupa, de Alto Laqaya a Bajo Laqaya, de la fortaleza en la colina escarpada a un establecimiento de tipo incaico en la llanura, organizado de acuerdo a un entramado jerarquizado de plazas. Y junto con ello, más aportes civilizatorios: la introducción de la agricultura y el tejido. Recorriendo las ruinas de Laqaya, siguiendo el sendero arqueológico interpretativo, don Justino lo expresaría en estos términos:

«Aquí ya no han vivido una vida bien reñida, atascada, sino que tenían una vida más tranquila.[...]. Y de Alto Laqaya a Bajo Laqaya. Digamos, estamos a media altura y... Y bueno, los incas aquí les han enseñado: [a] las mujeres a tejer, a hilar de la llama... de la lana de llama, de vicuña, de guanaco, a hacer ropas chompas, las polleras, los chulos, bueno todo eso; la parte de artesanías indígenas, la parte de artesanías en hilar, en fábrica, digamos las telas, pero en puro de lana de llama, de vicuña, así sucesivamente. Y [a] los hombres ya los han enseñado a labrar, con más capacidad, con más... o sea que... a trabajar en la tierra, como ser en la siembra de quinua, de ajara, el ilicuma, todo eso. Todos esos trabajos». (Justino Calcina Lupa, 41 años. 2002)

Se pone aquí en juego una valoración de los incas en tanto que civilizadores de los Andes, medida su actitud hacia las poblaciones nativas que van conquistando por lo que a su progreso 
(civilización) contribuyen. Sin embargo, así planteado pareciera que los chullpas iban desnudos, y que fueron los incas quienes les enseñaron a cubrir su cuerpo. Sin embargo, los cuerpos momificados que aparecen en el interior de algunas torres chullpas (aquellos chullpas que, sorprendidos por los primeros rayos de sol, murieron secados en sus casas) ya aparecen vestidos, algo que, por lo tanto, resulta paradógico. Don Fermín Bernal Ticona es un hombre que no aparenta su edad, menudo, vivaracho y bromista, dedicado a sus chacras y, hasta noviembre de 2004, Tata Umachi de su comunidad, algo así como, dentro de los «guardianes de la tradición, de las costumbres», el conductor principal de los rituales comunitarios. Conversando una noche sobre el aspecto de los chullpas, y al hilo de esta paradoja de que los incas lleven el arte textil a unos chullpas que ya van vestidos, me comentó lo siguiente:

«Como un chumpi, dicen, que tendrían sus vestidos. Un chumpi enterito, de un solo color. De lana sería, pues claro». (Fermín Bernal Ticona, 75 años. 2002)

En otra ocasión, charlando sobre esos chullpas que aparecen desecados al interior de algunas torres chullpa de las inmediaciones de Santiago, don Erasmo apuntó algo parecido:

«Hay gente que tenía incluso vestimenta, que era en tres colores nada más: café, como guindo había, y azul. Así, se usaba, como aguayito. Su vestimenta de esa gente, dicen. ¿De qué tiempo sería?». (Erasmo Condori Ticona, 59 años. 2001)

En cuanto a la agricultura pasaría otro tanto de lo mismo, y de hecho, lo que a este respecto matizaba don Justino en su relato era que los incas introdujeron nuevos cultivos entre los chullpas, y les enseñaron, no tanto la práctica de la agricultura en sí, sino a «labrar con más capacidad». Según me cuentan, la economía de los chullpas se basaría en la cría de rebaños de llamas y en la agricultura, un arte de labrar la tierra que incluso resultaría más eficaz que el practicado hoy por los santiagueños, porque, gracias a esos citados poderes telúricos, los chullpas pudieron cultivar en mitad de pedregales y en suelos que hoy resultan estériles. Y precisamente, como me llamó la atención Wilson en una de nuestras salidas al campo, son estas chacras de los antiguos las que dan fe de su existencia pretérita:

«La gente antigua [...] mayormente ha debido cultivar, porque por eso miramos toda esta chacra; estas chacras seguramente han debido de sembrar. Toda esa falda y por ahí, por eso más que todo hay murallas [=pircados], que lo miramos por todas partes ¿no? Tal vez todo esté sembrado donde ha vivido la gente, porque en todas partes hay murallas no más. Exactamente no te puedo decir que han vivido así así, pero se ve que han vivido». (Wilson Condori Vilca 29 años. 2001)

Algo parecido me apuntaría don Fermín en una de nuestras conversaciones sobre los modos de vida de los chullpas:

«Aquí, en tierra mismo. Aquí en donde las chullpas. Igual donde están sus ayllus, pircaos, chullpaos... Ahí trabajaban, pues. Hacían a la tierra, con eso trabajaban. Así, que no tiene muralla, no, hay poquitas partes. Partes con murallitas, ésas eran sus murallas». (Fermín Bernal Ticona, 75 años. 2002)

Desde una lógica arqueológica, el problema que se deriva de estos dos testimonios sería el de poder determinar la antigüedad de dichos pircados, muchos de los cuales corresponden a momentos subactuales. Sin embargo, desde la óptica local, lo notorio es que, dentro de su condición de héroes culturales y civilizadores andinos, no fueron los incas quienes llevaron la agricultura a Lípez; tan sólo la perfeccionaron (aunque esto no sea poco).

Planteado el avance civilizador de los incas desde una perspectiva evolutiva, el desenlace podría presentarse en términos de un pueblo retrasado al que otro de cultura superior pacifica y regala los beneficios de la civilización, pasando así a un período idílico en el que ambos grupos conviven en buena armonía de mestizaje. Sin embargo, ¿cómo es posible que chullpas e incas convivieran en un mismo espacio-tiempo si los primeros habían sido abrasados por los rayos del sol primigienio? Efectivamente, esta es la versión mayormente aceptada y relatada por los santiagueños, la de que los chullpas habitaron una era lunar y que desaparecieron mucho antes 
de que los incas irrumpieran en Lípez. Pero hay también variantes de este mito que hablan de chullpas que sobreviven a este final, escondiéndose en cuevas y readaptándose poco a poco a esa nueva situación, dando lugar a una nueva generación de chullpas14. Así, un problema de definición del espacio-tiempo históricos en el que diferentes relatos (formas de concebir la historia) participan de una contingencia que depende de las representaciones de alteridades pretéritas, y que podría resolverse planteando la existencia de una renovada humanidad de chullpas o, lo que me parece más convincente, haciendo coincidir la salida del sol y la conquista incaica en un mismo pachacutic que pone fin a los chullpas. Enseguida retomaré esta hipótesis, pero ahora volvamos a la lectura que don Justino hace de la pax incaica.

Sea como fuere, la cuestión está en que la llegada de los incas implicaría a priori el establecimiento de la paz entre los chullpas y el principio de su proceso de civilización... aunque a la fuerza. Si antes don Justino había presentado la expansión del Tawantinsuyu considerando positivamente a los incas como pacificadores y civilizadores (vid supra), en el transcurso de aquella conversación fue cambiando poco a poco de opinión hasta terminar ofreciéndome una imagen negativa de la conquista incaica:

«Cuando los incas han llegado a colonizar a los chullpas [...] ha cesado la guerra... en fin, la guerra de las tribus, o de las nómades, o como se llame. Bueno, han sido ya expuestos al mando del Inca. Y el Inca... Cuando la llegada de los incas ya ellos han visto el paz, ya no había guerra, sino que los ha juntado el Inca, los ha unido. Y sí, también había matanzas entre incas y chullpas, pero como los incas eran hombres fuertes también... tenían más poder que los chullpas... los han dado el paz.

Por esas épocas los chullpas se consideraban dueños de sus tierras donde ellos habitaban ¿no?, pero los incas han venido recorriendo por muchos lugares, por toda esta parte que ahorita somos lo que Bolivia, Chile, Perú, Ecuador, bueno, Venezuela [sic], etc., bueno, Argentina, la parte [noroeste] de Argentina. Los incas se han expandido colonizando a los chullpas, y bueno, ahí los incas cobraban impuestos... o sea, cobraban impuestos pero los chullpas pagaban sus tributos con el trabajo, no así con dinero ni con sus riquezas». (Justino Calcina Lupa, 41 años. 2002)

La pacificación de los territorios conquistados es condición sine qua non para su posterior reordenamiento y explotación imperial. Como indica el relato de don Justino, esto no quita que dicha paz se lograra por la fuerza de las armas; ni tampoco desmiente que los chullpas guerrearan contra los incas, ya fuera para mantener su independencia o en respuesta subversiva a un nuevo orden colonial abusivo: violencia engendra violencia. Arqueología y etnohistoria corroboran esta historia: su organización político-militar superior hizo que los incas se impusieran primero sobre el resto de pueblos del altiplano central, y que luego se expandiera por el resto del área andina. Conquista, dominio e imposición tributaria, quizás un caro precio para la paz. En resumidas cuentas, que de igual manera que la llegada de los incas a Lípez implica el progreso de los chullpas, el triunfo de la civilización sobre la barbarie, por ende, estaría representando también la extinción de esa barbarie. Desgraciadamente, ésta ha sido una constante histórica: pacificar al potencial enemigo pasa por un incremento de la violencia, real y/o simbólica; aprehender al otro, en muchos casos, implica fagocitarlo. ¿Acabaron los incas con los chullpas? Don Justino parece tenerlo claro, y así remata su relato acerca de las consecuencias del proceso civilizador que los incas ejercieron sobre los chullpas, y que aquí he ofrecido dividido en cuatro fragmentos:

14 En este sentido, y en tanto que espacios naturales de comunicación entre mundos (al igual que los lagos y lagunas), las cuevas estarían actuando aquí como pacarinas, lugares míticos de origen. No es simplemente que los chullpas se refugien en ellas en momentos de crisis y, pasado un tiempo de readaptación, salgan de nuevo como si tal cosa. Más bien habría que verlas como puertas a otra dimensión, por las que una humanidad desaparece y de las cuales resurge otra nueva que poblará una «Edad» distinta. El hecho de que en Lípez no proliferen las cuevas (aunque sî los abrigos rocosos) nos situaría ante una constante dentro del orden andino de las cosas. 
Batallas del pasado en tiempo presente. «Guerra antigua», civilización y pensamiento local en Lípez

«También hay otra historia de que, bueno, cuando gente desconocida, gente foránea [los incas], que ellos [los chullpas] nunca han visto, han venido a colonizar... Bueno, también sería una época de esclavitud, cuando trabajan por mitas. [...]. Ellos les hacían trabajar brutalmente, de sol a sol, etc. Entonces mucha gente se escapaba, y han muerto en unas cuevas, en unos lugares medio invisibles». (Justino Calcina Lupa, 41 años, 2002)

Se señalaba primero que «los chullpas pagaban sus tributos con el trabajo», algo que encajaría con esa interpretación dada por Nielsen de Laqaya como colonia de mitimaes dedicados al laboreo en los campos del Estado o a la extracción de metales y/o sal (vid supra). Pero quizás lo más destacable sea que dicho tributo en trabajo acarreó nuevos problemas y hasta la extinción aparentemente definitiva de los chullpas, un final en el que las cuevas, nuevamente, parecen haber jugado un papel significativo. Como en aquel primer amanecer de los tiempos, algunos chullpas huyeron a refugiarse en cuevas, donde murieron en el olvido. Como planteaba más arriba, la cuestión es si podemos considerar que la salida del sol (mito) y la llegada de los incas (historia) correspondan en realidad a un mismo pachacutic. Como argumenté en otras páginas (Gil, 2005a; 2005b), en tanto que el Inca es hijo del Sol, incluso el Sol mismo, me parece que sí; una respuesta que, además, resuelve el problema de superposición, y a la vez yuxtaposición, de las Edades de Purum y Auca planteado por Guamán Poma al mezclar partes del pensamiento quechua y aymara sobre Tiempo y Espacio15.

La comunidad de Coquesa, en el borde septentrional del Salar de Uyuni, a los pies del volcán Tunupa, utiliza como uno de sus reclamos turísticos una gruta semiartificial en la que se han reunido bajo llave varios cuerpos momificados procedentes de distintos enterramientos de los alrededores. Esta es la versión oficial de las autoridades de la comunidad, que rescataron a esos chullpas de lo que consideraron un saqueo arqueológico. Sin embargo, otra interpretación de esta cueva y de los cuerpos albergados en su interior, que me contaron en la vecina comunidad de Jirira (agosto de 2001), habla de una familia de chullpas que en su huida desesperada de las huestes españolas se refugió en la gruta, donde murieron de hambre y de pena. Y esto resulta interesante en tanto que está describiendo otra situación de conquista posterior en el tiempo pero resulta de acuerdo a un mismo mecanismo de evasión, que mantiene el protagonismo de las cuevas como lugares de refugio y regeneración de una humanidad afectada por un cambio de orden radical 16 .

Volviendo a la cuestión del contacto entre incas y chullpas, y a tenor de lo presentado, guerra y civilización quedan estrechamente vinculadas: primero, una guerra de pacificación, a la que sigue un proceso de civilización que, nuevamente desemboca en guerra como consecuencia de lo que podría calificarse como resultados civilizatorios derivados en abusos y explotación. Ahora bien, más allá de los enfrentamientos, ¿de qué manera ha pasado a la memoria esa batalla contra el otro del tiempo de los incas?

En términos generales, los Incas actúan como héroes culturales civilizadores y reorganizadores del mundo andino. Desde esta perspectiva, y muy especialmente a la hora de generar autorrepresentaciones e identidades, la idea de civilización llevará aparejada la distinción «interno/externo», «propio/ajeno». El pueblo que tiene (auto)conciencia de civilizado será el que dicte los parámetros a partir de los cuales se pueda considerar el grado de civilización o barbarie

15 Remito al lector interesado a aquellas páginas, porque lamentablemente, repetir aquí toda la argumentación que me lleva a resolver esta hipótesis resultaría demasiado extenso para este trabajo, excediendo además los límites del tema que nos ocupa. Por otra parte, dicha cuestión constituye uno de los ejes fundamentales de mi Tesis Doctoral en curso (Gil, s/f) donde me centro en las construcciones mentales y la percepción territorial que guían un proceso de etnogénesis, iniciado por los incas y continuado por los españoles durante la Colonia temprana, del cual va a resultar la construcción de Lípez como región geohistórica.

16 Asimismo, este relato dilata la existencia de los chullpas. ¿Quién dijo que hubieran desaparecido para siempre? Los chullpas existen, ya hayan pasado a formar parte del universo de entidades telúricas causantes de enfermedad, ya sea como restos despistados de aquella otra humanidad que, de vez en cuando, el folklore hace (re)aparecer en alguna comunidad como devoradores de niños... Pero esas son otras historias, otros relatos. 
de los demás. De esta manera, es la progresión hacia aquellos logros de los que éste se sienta más orgulloso lo que marca el proceso de civilización de los otros; consecuentemente, el ideal civilizatorio desborda las fronteras y rige las empresas de conquista y colonización de esos otros pueblos atrasados/primitivos. Por este mismo mecanismo, la Historia (siempre etnocéntrica) decidirá dónde se encuentra el orígen de cada civilización y cuáles son los pueblos civilizados por antonomasia.

En consecuencia, será un criterio de presencia/ausencia de determinados elementos portadores de civilización lo que guíe la conciencia y la memoria históricas de un pueblo en la búsqueda de sus orígenes civilizados y la selección de sus héroes civilizadores. Lo mismo para la Tradición. Sin embargo, los santiagueños no remontan su herencia cultural a los antiguos chullpas, expresión de una humanidad salvaje, aunque tampoco (como en la mayor parte del mundo andino) a los incas. Así me lo haría notar don Erasmo, una tarde, conversando sobre la recreación del contacto hispano-indígena en el marco local y regional:

«Ese tiempo ya no es de esta gente, [los chullpas son de] más antes, porque cuando llegaron [los españoles] eran los incas; los incas y los quechuas eran los gentiles, otra gente. Pero según nos dice el doctor Axel [Nielsen], nosotros seríamos descendientes de ellos, de los chullpas, pero no creo. Esa gente a saber de cuándo habría existido. No creo, ojalá que lleguemos a saber». (Erasmo Condori Ticona, 59 años, 2001)

«Los incas y los quechuas eran los gentiles»... ¿ Es esta misma idea de gentiles la que se está utilizando en las Crónicas de Indias para referirse a los pueblos que habitaron el altiplano antes que los incas? ¿Acaso no se refiere en ese contexto a los antiguos en general, concepto éste que ha pasado a las tradiciones orales? ¿No equivalen en una de sus acepciones los chullpas a esos gentiles/antiguos? Habría que dedicar más tiempo a tratar de concretar la persona de los chullpas, y también a esclarecer esta ambigua secuencia cronológica del pensamiento de las gentes de Santiago (v.gr. Gil, 2005a; 2005b; 2005c) pero en cualquier caso una cuestión queda clara: fueron los incas quienes ganaron la batalla contra el otro y regalaron a sus vencidos chullpas la Civilización, aunque con ello causaran también su desaparición y provocaran un cambio de era en el tiempo de la tradición y la memoria.

\section{CONSIDERACIONES FINALES}

Historia, Tradición, Memoria... el caso es que reconstruimos (o mejor, recreamos) el pasado a través de la proyección de nuestra propia manera de entender el mundo y la realidad, desde nuestro propio presente. Por este motivo, en estas páginas he tratado de presentar cómo los santiagueños representan a una parte de sus alteridades, la que habitó en otros tiempos y de la que reconocen su existencia a partir de las ruinas. Lo que este ejercicio confirma es que todos inventamos períodos y gentes del pasado, porque necesitamos concretar los cambios por los que atraviesa nuestra marcha identitaria del pasado al presente y de camino al futuro. Por este motivo, a consecuencia de nuestro propio devenir, y según la representación que nos formemos del tiempo que nos toca vivir, recreamos períodos y gentes a los que denostamos o ensalzamos. $\mathrm{Y}$ en ese caminar hacia delante, la civilidad siempre ha estado flanqueada por la imagen del primitivo, del bárbaro, del salvaje.

Desde estos parámetros, en la guerra influyen la imagen que un grupo crea de sí mismo y la que proyecta sobre sus enemigos, tanto o más que aquello que dicho grupo necesite o ambicione. En este sentido, si la guerra antigua es en realidad una recreación de una guerra antes de la civilización, creo que este ejercicio de releer batallas del pasado en tiempo presente permite escudriñar en el pensamiento local ideas de identidad (histórica, si quisiéramos adjetivarla) y civilización. Los chullpas, en tanto que máxima expresión de alteridad, son unos personajes escurridizos; en tanto que salvajes, los chullpas vivían en un estado permanente de guerra, algo a lo que la pax incaica pondría fin por medio de un proceso de civilización. ¿Acaso hay 
mejor manera de destacar la alteridad que dibujando un mundo salvaje, sin reglas, anárquico y violento? Por este motivo pienso firmemente que profundizar en la guerra antigua permite ahondar en los mecanismos del pensamiento local para representar la alteridad, ordenar el tiempo y, en definitiva, sentar los cimientos de la identidad.

Sin embargo, me parece que es éste el momento de retomar esa duda metodológica ya enunciada con anterioridad, y que plantea hasta qué punto el pensamiento local no estará reconstruyendo el tiempo de los antiguos a partir de ideas arqueológicas más o menos trilladas, difundidas por los textos escolares y/o tomadas directamente de la interacción con equipos arqueológicos.

A este respecto comentaré que, desde sus primeras investigaciones hace ya casi una década, el equipo del Proyecto Arqueológico «Altiplano Sur» que dirige el Dr. A. E. Nielsen (CONICET, Argentina) ha trabajado siempre en estrecha colaboración con las comunidades locales de diferentes sectores de Lípez. Por lo que a Laqaya se refiere, Santiago actuó siempre como base de operaciones de sus campañas de campo, lo que facilita una interacción mayor con la población local. Además, los miembros de esta comunidad y de la vecina Santiago Chuvica han participado activamente en trabajos arqueológicos de distinto calibre desarrollados en el sitio, y en ambas poblaciones se realizaron diferentes talleres conducentes a la consolidación y acondicionamiento del yacimiento para su posterior apertura a visitas guiadas por personal local (Nielsen et al., 2003: 274-277). En este sentido, tal vez esta implicación local en lo arqueológico haya podido modificar parte del discurso local tradicional acerca de, por ejemplo, la antigüedad de las ruinas, su distribución interna y/o la interpretación de algunas de las estructuras arquitectónicas. Sin embargo, son dos los elementos que me llevan a minimizar esta posible influencia externa. De un lado, el hecho de que Nielsen (comunicación personal) ya registró en su día testimonios similares a los aquí presentados, especialmente en lo tocante a la aparición del sol en el firmamento y la muerte de los chullpas. Además, la opinión de don Erasmo contradiciendo a los arqueólogos acerca de que los santiagueños serían descendientes de los chullpas (vid supra).

Por otro lado, cuando en 2002 pedí a los alumnos del Núcleo Educativo «Miguel Cuzco» que me hicieran un dibujo de Laqaya, sí es cierto que algunos de ellos representaron junto a las ruinas artefactos arqueológicos idénticos a los que ilustran sus textos escolares de Historia de Bolivia. Por regla general, casi todos los dibujos representaron el sitio como un conjunto de torreschullpa entre las cuales aparecían dispuestos huesos y calaveras, siendo igualmente frecuentes las puntas de flecha y algunas formas cerámicas que los alumnos rotulaban como vaso, plato, vasija, jarro, etc. Sin embargo, me llamaron la atención los perfectos keros que Nora Delina Valda Vilca, de 4 o Intermedio, incluía en su dibujo, acompañados de una vasija con forma de llama y un aríbalo también de tipo inca, dos motivos que se repetían en los trabajos de varios de sus compañeros de Segundo Ciclo; esto fue lo que me movió a echar un vistazo a los textos escolares. Tratándose de niños realizando una tarea escolar, me parece que esto respondería más bien a una voluntad artística por enriquecer y embellecer los dibujos que a una verdadera influencia del pensamiento arqueológico en el pensamiento local. Además, de dónde si no iba a venirle a Héctor Quispe Muraña, de 10 Intermedio, la idea de colocar entre las torreschullpa el monolito Ilamado El Fraile, sito en Tiwanaku, o a Ana Calcina, de 70 Inicial, y a Vanesa Niña Calcina, de 40 Intermedio, la inspiración para coronar el pukara de Alto Laqaya con la también tiwanakota Puerta del Sol... La proyección de las ruinas quizás más emblemáticas para el pensamiento nacional boliviano sobre las más representativas para el pensamiento local santiagueño; sin duda, un claro ejemplo de monumentalización de la memoria.

Con todo, y volviendo a la guerra antigua, queda patente que ordenar la Historia no consiste (o por lo menos, no debería consistir) tan sólo en presentar una relación secuencial de acontecimientos, muy especialmente cuando dicho discurso histórico se proyecta hacia un pasado instalado en la atemporalidad del Mito y sobre unos personajes que pasan a asentarse firmemente en la Tradición. Pero desde este enfoque, tampoco debería limitarse simplemente a una revisión formal de las estructuras narrativas de las mitológicas y/o de la tradición oral. Considero por tanto que tratar de etiquetar este particular análisis de la guerra en el mundo andino como un trabajo de arqueología, (etno)historia o etnografía, carece de relevancia, si no 
es incluso que resulta contraproducente. Mi intención en estas páginas ha sido la de abordar una visión del otro que nos permita seguir viendo a otros: las gentes de Santiago, los chullpas, los incas, incluso (y de pasada) los españoles, distintas formas de construir identidades y alteridades, todo ello tomando como telón de fondo la guerra antigua, una guerra antes de la civilización. Es por ello que he optado por combinar los datos provenientes de la arqueología y de las Crónicas de Indias con el testimonio de los santiagueños. A fin de cuentas, los relatos de Guamán Poma, Cieza de León y el Padre Cobo corresponden igualmente a una tradición oral puesta por escrito hace varios siglos, con todas las implicaciones que ello revierte para la crítica de fuentes, y que aquí han sido apuntadas someramente. Y si la arqueología otorga a estos autores fiabilidad como fuente documental y gráfica, y confía en ellos a la hora de apoyar y validar sus interpretaciones, ¿por qué no hacer lo mismo con el relato etnográfico?

Para las gentes de Santiago, el pasado habitado por los chullpas existió en tanto que ahí están sus ruinas; recordemos las palabras de Wilson: «no te puedo decir que han vivido así así, pero se ve que han vivido» (vid supra). Por tanto, es a partir de estos espacios como ellos establecen su relato de los hechos, dando así lugar a un pasado recreado desde las evidencias presentes, las mismas que se toman como referente a la hora de definir la naturaleza de quienes habitaron dicho pasado. Así por ejemplo, si hay murallas es porque hubo guerra, y si las murallas son bajas es porque los chullpas fueron enanos. Una lógica tan válida como cualquier otra. Con razonamientos como éstos es por lo que afirmo que el tiempo de los chullpas es recreado a partir de una serie de hitos monumentales que generan la representación de acontecimientosen-el-espacio desde los que se articulan distintos relatos sobre el pasado y sus habitantes.

Desarrollar una investigación sobre la guerra antigua a partir de la tradición oral, igual aquella de la cual se hicieron eco los Cronistas que la recogida hoy entre las comunidades altiplánicas, implica trabajar con acontecimientos y descripciones dados por verídicos pero cuya constatación arqueológica resulta cuando menos complicada. Pensemos por ejemplo que, de no ser por las Crónicas, un arqueólogo tendría muy difícil (por no decir que le resultaría imposible) determinar exclusivamente en función de restos materiales distintas tácticas militares, composición interna de los ejércitos, códigos de honor, y un largo etcétera de aspectos ligados al arte de la guerra. Y en definitiva, a través del análisis de las historias de ruinas todas estas cuestiones también se han ido perfilando en las páginas de este trabajo. Simplemente, desde otro punto de vista, aquel que considera la guerra andina en términos de una guerra antes de la civilización.

\section{Agradecimientos}

Desde aquí quisiera expresar mi agradecimiento a los doctores Carmen Bernand, Capucine Boidin, Thérèse Bouysse-Cassagne, Jean-Pierre Chaumeil, Gerardo Fernández Juárez, Manuel Gutiérrez Estévez, Luis J. Ramos Gómez y Josefa Salomón, por sus comentarios a distintas versiones de este trabajo, aunque la responsabilidad del resultado final es enteramente mía. Así mismo, a D. Fermín Bernal Ticona, D. Justino Calcina Lupa, D. Erasmo Condori Ticona, D. Wilson Condori Vilca y al joven Franz Gonzalo Quispe Cayo, todos de la comunidad de Santiago «K», por su paciencia ante mis preguntas sobre la guerra antigua y por su buena disposición para guiarme entre las ruinas de Laqaya. 
Batallas del pasado en tiempo presente. "Guerra antigua», civilización y pensamiento local en Lípez

\section{Referencias citadas}

ARELLANO LÓPEZ, J., 2000 - Arqueología de Lipes. Altiplano Sur de Bolivia, 284 p.; Quito: Pontificia Universidad Católica de Ecuador-Museo Jacinto Jijón Caamaño-Taraxacum.

ARELLANO LÓPEZ, J. \& BERBERIÁN, E. E., 1981 - Mallku: el señorío post-Tiwanaku del Altiplano Sur de Bolivia (Provincias Nor y Sur Lípez - dpto. de Potosí). Bulletin del Institut Français d'Études Andines, 10 (1-2): 51-84.

BARTRA, R., 1996 - El salvaje en el espejo, 347 p.; Barcelona: Destino.

BARTRA, R., 1997 - El salvaje artificial, 478 p.; Barcelona: Destino.

CAMINO, A., 1977 - Trueque, correrías e intercambio entre los Quechuas andinos y los Piro y Machiguenga de la Montaña peruana. Amazonía Peruana, 1 (2): 123-140.

CERPA BUSTAMANTE, B. R., 2001 - Estrategia de conquista en el estado inca, 458 p.; Lima: Universidad Nacional Agraria La Molina.

CIEZA DE LEÓN, P., 1984 [1553] - La crónica del Perú (Ballesteros, M., ed.), 414 p.; Madrid: Historia 16, Crónicas de América 4.

CIEZA DE LEÓN, P., 1986 [1550-54] - Descubrimiento y conquista del Perú (3a parte de la Crónica del Perú) (Sáez de Santa María, C., ed.), 339 p.; Madrid: Historia 16, Crónicas de América 17.

CLASTRES, P., 1974 - La société contre l'État: recherches d'anthropologie politique, 186 p.; Paris: Éditions de Minuit.

CLASTRES, P., 2001 [1977] - Arqueología de la violencia: la guerra en las sociedades primitivas. In: Investigaciones en antropología política [1980]: 181-216; Barcelona: Gedisa.

COBO, B., 1964 [1653] - Historia del Nuevo Mundo. In: Obras completas del P. Bernabé Cobo (Mateos, F., ed.) [1956], 2 vols.: vol. I, 439 p. y vol. II: 1-275; Madrid: Biblioteca de Autores Españoles - Atlas.

DUVIOLS, P., 1980 - Periodización y política: la historia prehispánica del Perú según Guamán Poma de Ayala. Bulletin de l'Institut Français d'Études Andines, 9 (3-4): 1-18.

FAUSTO, C., 2002 - Banquete de gente: comensalidade e canibalismo na Amazônia. Mana, 8 (2): 7-44.

GIL GARCÍA, F. M., 2001 - Secuencia y consecuencia del fenómeno chullpario. En torno al proceso de semantización de las torres chullpa. Anales del Museo de América, 9: 165199.

GIL GARCÍA, F. M., 2002 - Donde los muertos no mueren. Culto a los antepasados y reproducción social en el mundo andino. Una discusión orientada al manejo del Tiempo y el Espacio. Anales del Museo de América, 10: 59-83.

GIL GARCíA, F. M., 2005a - Tres cárceles para los chullpas. Persona, tiempo y espacio de «los antiguos» en el pensamiento andino. Revista electrónica Nuevos Mundo, Mundos Nuevos, 4. http://www.ehess.fr/cerma/Revue/indexCR.htm [en edición]

GIL GARCÍA, F. M., 2005b - Las ruinas, la iglesia, la mina. Identidad local y construcción del discurso histórico en una comunidad del Altiplano de Lípez (Dpto. Potosí, Bolivia). Actas del XI Congreso Internacional de la Sociedad Española de Americanistas. Murcia. [en prensa]

GIL GARCíA, F. M., 2005c - Retratando a los chullpas, ordenando el tiempo de los antiguos. Ruinas y pensamiento local en Lípez (Dpto. de Potosí, Bolivia). Thule. Rivista italiana di studi americanistici, № especial de Actas del XXIV Congreso Internacional de Americanística (Perugia, 10/12-5-2002). [en prensa, i2005?]

GIL GARCÍA, F. M., 2005d - Cuando vengan los turistas... Ruinas arqueológicas, turismo y expectativas de locales futuro en Nor Lípez (Dpto. Potosí, Bolivia). Textos Antropológicos, 15 (2). 
GIL GARCíA, F. M., s/f - Lipes en los siglos XIV-XVII. Construcción de una región geohistórica identitaria en el altiplano surandino y clasificaciones coloniales. Tesis para optar al grado de Doctor en Historia de América por la Universidad Complutense de Madrid. Ms.

GORBAK, C., LISCHETTI, M. \& MUÑOZ, C. P., 1962 - Batallas rituales del chiaraje y del tocto de la Provincia de Kanas (Cuzco - Perú). Revista del Museo Nacional, XXXI: 245-304.

GUCHTE, M. van de, 1984 - El ciclo mítico andino de la Piedra Cansada. Revista Andina, 2 (2): 539-556.

GUILAINE, J. \& ZAMMIT, J., 2002 - El camino de la guerra. La violencia en la prehistoria [2001], 283 p.; Barcelona: Ariel.

HERNANDO, A., 1997 - Sobre la prehistoria y sus habitantes: mitos, metáforas y miedos. Complutum, 8: 247-260.

HOBBES, T., [1651] - Leviatán o la materia, forma y poder de una república eclesiástica y civil; varias ediciones.

KEELEY, L. H., 1996 - War before civilization, 245 p.; Nueva York - Oxford: Oxford University Press.

LÉVY-STRAUSS, C., 1943 - Guerre et comerce chez les Indies de I'Amerique du Sud. Renaissance, I (1-2): 122-139.

NIELSEN, A. E., 1997 - Primeras evidencias de la presencia inka en el altiplano de Lípez (Potosí, Bolivia). Actas del XII Congreso Nacional de Arqueología: 280-293. La Plata.

NIELSEN, A. E., 1998 - Tendencias de larga duración en la ocupación humana del altiplano de Lípez (Potosí, Bolivia). In: Los desarrollos locales y sus territorios. Arqueología del NOA y sur de Bolivia (Cremonte, M. B., ed.): 65-102. San Salvador de Jujuy: Universidad Nacional de Jujuy.

NIELSEN, A. E., 2001 - Evolución del espacio doméstico en el norte de Lípez (Potosí, Bolivia): ca. 900-1700. Estudios Atacameños, 21: 41-61.

NIELSEN, A. E., 2002 - Asentamientos, conflicto y cambio social en el Altiplano de Lípez (Potosí, Bolivia). Revista Española de Antropología Americana, 32: 179-205.

NIELSEN, A. E., CALCINA, J. \& QUISPE, B., 2003 - Arqueología, turismo y comunidades originarias. Una experiencia en Nor Lípez (Potosí, Bolivia). Chungara, Revista de Antropología Chilena, 35 (2): 369-377.

OSSIO, J., 1973 - Guamán Poma: Nueva Coronica y Buen Gobierno o Carta al Rey. Un intento de aproximación a las categorías de pensamiento del mundo andino. In: Ideología mesiánica del mundo andino (Ossio, J. ed.): 155-207; Lima: Ignacio Prado Pastor Editor.

OSSIO, J., 1976-1977 - Guamán Poma y la historiografía indianista de los siglos XVI y XVII. Historia y Cultura, 10: 181-206.

OSSIO, J., 1977 - Las cinco edades del mundo según Felipe Guamán Poma de Ayala. Revista de la Universidad Católica, 2/Diciembre: 43-58.

PLATT, T., 1986 - Mirrors and maize: the concept of yanantin among the Macha of Bolivia. In: Anthropological history of the Andea polities (Murra, J., Wachtel, N. y Revel, J., eds.): 228-259; Cambridge: Cambridge University Press.

POMA DE AYALA, F. G., 1987 [1615] - Nueva crónica y buen gobierno (Murra, J., Adorno, R. y Urioste, J. L., eds.), 3 vols., 1384 p.; Madrid: Historia 16, Crónicas de América 29 a-c.

ROWE, J., 1963 [1946] - Inca culture at the time of Spanish conquest. In: Handbook of South American Indians (Steward, J., ed.), II: 183-330; Nueva York: Cooper Square [Washington: Smithsonian Institution].

SPEDDING, A., 1993 - Semiótica de la cocina paceña. O «porquerías que se hacen pasar por comida». Revista UNITAS, 10: 51-64.

TOPIC, J. R. \& TOPIC, T. L., 1997 - Hacia una comprensión conceptual de la guerra andina. In: Arqueología, antropología e historia. Homenaje a María Rostworowski (Varón R., y Flores, J., eds.): 567-590; Lima: Instituto de Estudios Peruanos. 